\title{
Extrahepatic manifestations of hepatitis E virus: An overview
}

\author{
Fotios S. Fousekis, loannis V. Mitselos, and Dimitrios K. Christodoulou \\ Department of Gastroenterology and Hepatology, University Hospital of loannina, School of Health Sciences, University of loannina, \\ loannina, Greece
}

Hepatitis E virus (HEV) is a significant health problem with approximately 20 million individuals infected annually. HEV infection has been associated with a wide spectrum of extrahepatic manifestations, including neurological, hematological and renal disorders. Guillain-Barré syndrome and neuralgic amyotrophy are the most frequent neurological manifestations. In addition, HEV infection has been observed with other neurological diseases, such as encephalitis, myelitis and Bell's palsy. Hematologic manifestations include anemia due to glucose-6-phospate dehydrogonase deficiency, autoimmune hemolytic anemia and severe thrombocytopenia. Membranoproliferative glomerulonephritis and relapse $\operatorname{Ig} A$ nephropathy with or without coexisting cryoglobulinemia appear to be the most common renal injuries related with HEV infection. Also, HEV infection has been associated with acute pancreatitis and other immune-mediated manifestations, such as arthritis and myocarditis. However, the pathophysiologic mechanisms of HEV-related extrahepatic manifestations are still largely unclear. (Clin Mol Hepatol 2020;26:16-23)

Keywords: Hepatitis E; Kidney; Neurologic manifestations; Hematologic diseases

\section{INTRODUCTION}

Hepatitis $E$ virus (HEV) is a single-stranded RNA virus and was first discovered in 1983, ${ }^{1}$ but the viral genome was cloned in 1990. ${ }^{2}$ It is estimated that HEV causes 20.1 million infections annually, leading to 3.4 million symptomatic cases with acute hepatitis and 70,000 deaths related to acute liver failure. ${ }^{3}$

HEV has eight genotypes. Genotypes 1 and 2 only infect humans, are detected mainly in Asia and Mexico, respectively and they spread through fecal-oral route. Genotypes 3 and 4 are detected mainly in Europe and North America, circulate in animal species such as pigs, wild boars and deer and occasionally infect humans via consumption of contaminated meat or direct contact. ${ }^{4}$ Also, genotype 3 has been detected in shellfishes in Scotland and in southern Italy., ${ }^{5,6}$ Genotypes 5 and 6 have been only reported in wild boar and genotypes 7 and 8 have been identified in camels. ${ }^{7}$

The diagnostic tests for HEV infection include detection of antibodies against HEV (IgM anti-HEV and IgG anti-HEV) and detection of HEV RNA. IgM anti-HEV is positive during the first month after HEV infection, while IgG anti-HEV represents current or past infection. ${ }^{8}$ Detection of HEV RNA in blood or stool characterizes chronic or acute HEV infection. Chronic hepatitis $E$ is defined as

\section{Abbreviations:}

AlHA, autoimmune hemolytic anemia; DAT, direct antiglobulin test; G-6PD, glucose-6-phospate dehydrogenase; GBS, Guillain-Barré syndrome; HAV, hepatitis A virus; HBV, hepatitis B virus; HEV, hepatitis E virus; MGUS, monoclonal gammopathy of undetermined significance; NA, neuralgic amyotrophy
Corresponding author : Dimitrios K. Christodoulou

Department of Gastroenterology and Hepatology, University of Ioannina, Stavrou Niarchou 1, Ioannina 45100, Greece

Tel: +302651099639, Fax: +302651007838

E-mail: dchristodoulou@gmail.com

https://orcid.org/0000-0001-9694-1160

Received : Sep. 3, 2019/ Accepted : Sep. 16, 2019

Copyright $\odot 2020$ by Korean Association for the Study of the Liver

This is an Open Access article distributed under the terms of the Creative Commons Attribution Non-Commercial License (http://creativecommons.org/licenses/by-nc/3.0/) which permits unrestricted non-commercial use, distribution, and reproduction in any medium, provided the original work is properly cited. 
HEV RNA being detectable for at least 3 months. In immunosuppresed patients with chronic HEV infection, antibodies are often undetectable. ${ }^{9} \mathrm{HEV}$ infection is usually self-limiting and causes acute mild illness. However, HEV infection during pregnancy, especially in the third trimester may lead to acute liver failure. ${ }^{10}$ Chronic HEV infection is rare and may develop in immunocompromised patients, such as organ transplant recipients."

In addition, HEV has been associated with a range of extrahepatic manifestations, including a spectrum of neurological symptoms and diseases, hematological disorders, renal diseases, acute pancreatitis, myocarditis, arthritis and autoimmune thyroiditis (Table 1). ${ }^{12}$ However, the pathophysiologic mechanism of extrahepatic manifestations remains unclear. It seems that viral infections trigger a variety of host-defense mechanisms, which may not be

Table 1. Extrahepatic manifestations associated with hepatitis E virus infection

\begin{tabular}{|c|c|}
\hline System & Manifestations \\
\hline $\begin{array}{l}\text { Neurological } \\
\text { system }\end{array}$ & $\begin{array}{l}\text { Guillain-Barré syndrome } \\
\text { Neuralgic amyotrophy } \\
\text { Encephalitis } \\
\text { Myelitis } \\
\text { Myositis } \\
\text { Vestibular neuritis } \\
\text { Peripheral neuropathy } \\
\text { Bell's palsy } \\
\text { Mononeuritis multiplex } \\
\text { Seizure } \\
\text { Pseudotumor cerebri } \\
\text { Oculomotor palsy } \\
\text { Polyradiculoneuropathy }\end{array}$ \\
\hline $\begin{array}{l}\text { Hematological } \\
\text { system }\end{array}$ & $\begin{array}{l}\text { Thrombocytopenia } \\
\text { Monoclonal gammopathy of uncertain } \\
\text { significance (MGUS) } \\
\text { Hemolytic anemia } \\
\text { Aplastic anemia } \\
\text { Hemophagocytic syndrome } \\
\text { CD30 (+) cutaneous T cell lymphoproliferative } \\
\text { disorder } \\
\text { Thrombotic thrombocytopenic purpura }\end{array}$ \\
\hline Kidney & $\begin{array}{l}\text { Relapse of IgA nephropathy } \\
\text { Cryoglobulinemia } \\
\text { Membranoproliferative glomerulonephritis }\end{array}$ \\
\hline Heart & Myocarditis \\
\hline Pancreas & Acute pancreatitis \\
\hline Thyroid & $\begin{array}{l}\text { Autoimmune thyroiditis } \\
\text { Subacute thyroiditis }\end{array}$ \\
\hline Skeletal system & Polyarthritis \\
\hline Vasculitis & Henoch-Schönlein purpura \\
\hline
\end{tabular}

restricted to the primary location of infection and can cause crossreactions between viral epitopes and self-antigens, leading to multisystemic manifestations. Another possible explanation is that HEV replicates not only in liver, but also in other tissues. HEV has been detected in neuronal cells, ${ }^{13}$ human placenta, ${ }^{14}$ breast milk, ${ }^{15}$ and urine. ${ }^{16}$

\section{NEUROLOGICAL MANIFESTATIONS}

Several neurological manifestations have been associated with HEV infection and include Guillain-Barré syndrome (acute inflammatory demyelinating polyradiculoneuropathy), neuralgic amyotrophy, encephalitis, myelitis, myositis, vestibular neuritis, peripheral neuropathy, Bell's palsy and mononeuritis multiplex. ${ }^{17}$ In a prospective multicenter study from United Kingdom, France and Netherlands it was found that 2.4\% (11/464) of patients with non-traumatic neurologic injury had evidence of HEV infection. ${ }^{18}$ Also, a study from France demonstrated the neurologic disorders in patients infected with HEV and found that $16.5 \%$ of HEV-infected patients reported neurologic symptoms and neurological manifestations were more frequent in immunocompetent patients compared to immunosuppressed patients ( $22.6 \%$ vs. $3.2 \%$, $P<0.001) .^{19}$ However, a study from China compared the prevalence of acute hepatitis $E$ between 1,117 patients diagnosed with neurological illness and 1,475 healthy controls and found that there was no difference $(0.54 \%$ vs. $0.68 \%) .{ }^{20} \mathrm{~A}$ possible explanation is the geographical distribution of HEV. The study from China was conducted in an area endemic for HEV genotype 4, while the European studies reported cases associated with HEV genotype 3 . Therefore, HEV genotype 4 seems not to contribute to neurological disorders. ${ }^{21}$

\section{Guillain-Barré syndrome}

Guillain-Barré syndrome (GBS) is an acute onset immune-mediated disorder of peripheral nervous system and is characterized by acute inflammatory demyelinating polyradiculoneuropathy, causing rapidly progressing symmetric motor paralysis. ${ }^{22} \mathrm{HEV}$ infection has been associated with development of GBS. Many studies have reported the high prevalence rate of HEV infection among GBS patients and several case reports have been documented showing the coexistence of acute hepatitis E with GBS. In Netherlands, 201 patients with GBS were compared with 201 healthy controls with a similar distribution in age, sex, and year of sampling and it 
was found that the prevalence of acute hepatitis $E$ was higher in patients with GBS compared with healthy controls (5\% vs. $0.5 \%) .{ }^{23}$ Additionally, in a similar study in Japan, $4.8 \%(3 / 63)$ of patients with GBS had acute HEV infection preceding the onset illness, while no patients from healthy control group (0/61) suffered from acute hepatitis E. Furthermore, a retrospective cohort study in Belgium found that the prevalence of HEV infection in patients with GBS was $8 \%(6 / 73){ }^{24}$ In all studies, there were no differences regarding course and outcomes of GBS between HEVrelated GBS and HEV-unrelated GBS. Also, cases of acute HEV infection have been found in pediatric patients with $G B S{ }^{25}$

\section{Neuralgic amyotrophy}

Neuralgic amyotrophy (NA), also known as Parsonage-Turner syndrome, is an acute and painful unique or multiple mononeuropathy in the upper extremity and is characterized by rapid multifocal motor weakness, amyotrophy and sensory loss. ${ }^{26}$ It seems that HEV infection can trigger the development of NA and several studies have been conducted. A cohort study with 64 patients from United Kingdom and Netherlands found that $10 \%$ of patients with NA had acute hepatitis E, but HEV was not related to age, sex, severity, disease course or outcome. ${ }^{27}$ Also, it seems that patients with NA and HEV have a distinct phenotype. A multicenter European study compared 61 HEV-NA patients with 61 NA patients and found that, HEV-NA appears more often predominately bilateral asymmetrical involvement $(80.0 \%$ vs. $8.6 \%$, $P<0.001)$ and more extensive damage to the brachial plexus. Involvement outside the brachial plexus is more common in HEVNA $(58.5 \%$ vs. $10.5 \%, P<0.01){ }^{28}$

\section{Other neurological manifestations}

Other neurological cases associated with HEV infection include vestibular neuritis, ${ }^{29}$ Bell's palsy, ${ }^{30}$ acute ataxic neuropathy, ${ }^{31}$ transverse myelitis, ${ }^{32}$ acute encephalic Parkinsonism ${ }_{1}{ }^{33}$ oculomotor palsy, ${ }_{1}^{34}$ myositis, ${ }^{35}$ seizure, ${ }_{1}^{36}$ pseudotumor cerebri, ${ }^{37}$ bilateral pyramidal syndrome, ${ }^{38}$ polyradiculoneuropathy, ${ }^{39}$ and mononeuritis multiplex. ${ }^{40}$ In addition, central nervous system infections, such as encephalitis and meningitis, with HEV have been reported and HEV RNA has been demonstrated in serum and cerebrospinal fluid at the time of acute illness. Also, many patients with CNS infection were immunosuppresed as a result of solid organ transplantation. $^{41}$

\section{Pathogenic mechanism}

The pathogenic mechanism between HEV and neurological disorders has been not clarified, but it seems that HEV is also neurotropic. Shedding of HEV RNA into the cerebrospinal fluid and intrathecal production of IgM anti-HEV has been detected in a patient with NA and acute HEV infection. ${ }^{42}$ Additionally, a study demonstrated that human neuronal-derived cell lines such as neuroepithelioma, desmoplastic cerebellar medulloblastoma, glioblastoma multiforme, glioblastoma astrocytoma and oligodendrocytic cells can support HEV RNA replication. ${ }^{43}$

It is recommended that clinicians consider the possibility of HEV infection in patients with neurological disorders and concurrent liver enzyme alteration, especially those with peripheral nerve involvement. $^{44}$

\section{RENAL MANIFESTATIONS}

Renal disorders have been reported during HEV infection, including membranoproliferative glomerulonephritis and cryoglobulinemia. A retrospective study assessed kidney function and histology in 51 cases of solid-organ transplant patients during genotype $3 \mathrm{HEV}$ infection and they observed statistically but not clinically significant decrease in estimated glomerular filtration rate $(-5 \mathrm{~mL} / \mathrm{min}, P=0.04)$ during HEV infection. In renal biopsies, glomerular diseases were identified. They included relapse of IgA nephropathy and membranoproliferative glomerulonephritis. The majority of these patients had cryoglobulinemia. After HEV clearance, cryoglobulinemia resolved and proteinuria and renal function improved. ${ }^{45}$ Additional cases of HEV-related membranoproliferative glomerulonephritis and membranous nephropathy have been reported. ${ }^{46,47}$ In one case, HEV infection triggered monoclonal gammopathy of renal significance. ${ }^{48}$

The association between cryoglobulinemia and HEV infection has not been fully investigated. In a study with solid organ recipients, who suffered from HEV infection, the prevalence of cryoglobulinemia was increased during chronic phase of infection (52.9\%) compared to acute phase of infection (36.4\%) and HEVnegative solid organ recipients (23.6\%) $(P<0.01)$. Also, HEV infection was identified as an independent predictive factor for cryoglobulinemia (odds ratio, 2.3). ${ }^{49}$ Another retrospective study from Germany compared the prevalence of IgG anti-HEV between patients with cryoglobulinemia and healthy controls. They found that the anti-HEV seroprevalence rate was significantly higher in 
Fotios S. Fousekis, et al.

patients with essential cryoglobulinemia than in non-essential cryoglobulinemia patients $(P=0.043)$, suggesting that previous HEV contact might play a role in some cases of cryoglobulinemia that are currently classified as essential. ${ }^{50}$

\section{HEMATOLOGIC MANIFESTATIONS}

\section{Anemia}

Different patterns of anemia have been reported during HEV infection, including hemolytic anemia due to glucose-6-phospate dehydrogonase (G-6-PD) deficiency, autoimmune hemolytic anemia (AIHA) and aplastic anemia. Hemolytic anemia may be a complication of acute viral hepatitis and the frequency rate of hemolysis has been reported in up to $23 \%$ of patients. The prevalence of hemolytic anemia may rise up to $70 \%$ in patients who have G-6-PD deficiency. ${ }^{51}$ Patients with G-6-PD deficiency have low levels of glutathione in red blood cells, leading to accumulation of oxidants during viral hepatitis and resulting in hemolysis. Several cases of hemolysis in patients with G-6-PD deficiency and acute HEV infection have been reported. ${ }^{52-54}$ In some cases of hemolysis in patients with acute HEV infection and G-6-PD deficien$c y$, there was development of renal failure, as a result of possible obstruction of renal tubules due to hemoglobulin and bilirubin. ${ }^{55,56}$

Autoimmune hemolytic anemia has been described in association with a variety of hepatotropic viruses, such as cytomegalovirus, hepatitis A virus (HAV) and hepatitis B virus (HBV). ${ }^{57} \mathrm{AlHA}$ is diagnosed based on clinical presentation, spherocytosis, laboratory findings and positive direct antiglobulin test (DAT). However, DAT was negative up to $15 \%$ of AlHA cases. In four published cases of AlHA-related with hepatitis $E$, the treatment was supportive and their outcomes were favorable. ${ }^{58-61}$

Hepatitis-associated aplastic anemia is an uncommon but distinct variant of aplastic in which pancytopenia appears 2 or 3 months after an acute attack of viral hepatitis. Several viruses, such as parvovirus B19, cytomegalovirus, Epstein-Barr virus, HAV and HBV, have been associated with aplastic anemia. ${ }^{62}$ Three cases of HEV-related aplastic anemia have been reported. In one case there was no response to treatment with cyclosporine and in the second case, the patient expired due to sepsis and in the third case, the patient was treated with thymoglobulin, cyclosporine, corticosteroids, filgastrim and transfusions. ${ }^{63-65}$

\section{Thrombocytopenia}

Thrombocytopenia is a well-recognized complication of infections, including those from hepatotropic viruses. A variety of possible mechanisms of thrombocytopenia have been reported and includes hypersplenism, reduced hepatic production of thrombopoietin, bone marrow suppression by hepatotropic virus or treatment and development of anti-platelet autoantibodies and platelet-associated immune complexes. ${ }^{66}$ Several cases of HEVassociated thrombocytopenia have been documented. In most cases, thrombocytopenia was self-limited, while in other cases, the patients needed to receive platelet transfusion, intravenous globulin and/ or corticosteroid. It is worth mentioning that, antiplatelet antibodies were detected in some cases of HEV-related thrombocytopenia. $44,61,67,68$

\section{Other hematological diseases}

HEV infection has been related with other less common hematological disorders. Few cases of HEV-related hemophagocytic syndrome have been documented. ${ }^{69-71}$ Also, HEV infection has been detected in patients with CD30 (+) cutaneous T cell lymphoproliferative disorder ${ }^{72}$ and monoclonal gammopathy of undetermined significance (MGUS). However, the relation between MGUS and HEV remains uncertain. ${ }^{73}$ Additionally in one case, thrombotic thrombocytopenic purpura relapse induced by acute hepatitis E transmitted by cryosupernatant plasma. HEV infection treated with ribavirin and thrombotic thrombocytopenic purpura remitted with remission of HEV infection. ${ }^{74}$

\section{ACUTE PANCREATITIS}

A wide variety of infectious agents has been associated with acute pancreatitis and these include viruses, bacteria and parasites. The association between acute pancreatitis and viral hepatitis is well known and HAV, HBV, and hepatitis C virus have been implicated most often. ${ }^{75,76}$ A proposed pathogenetic mechanism is the development of edema of the ambulla of Vater, causing obstruction of pancreatic fluid flow. ${ }^{77}$ Several cases of HEV-induced acute pancreatitis have been reported. ${ }^{78,79}$ In a single-center study from France, 2.1\% (16/790) of patients with acute pancreatitis had serological evidence of recent HEV infection with no other discernible cause of pancreatitis. ${ }^{80}$ The typical profile of a patient is a young male from an endemic area or having recently travelled 
to that area, who develops mild to moderate acute pancreatitis. ${ }^{81}$ However, life-threatening complications, such as, acute necrotizing pancreatitis, pseudocyst bleeding and multiorgan failure, have been reported. ${ }^{82-84}$

\section{OTHER MANIFESTATIONS}

Development of many other diseases has been reported during HEV infection, but further studies are needed to establish the association. In previous literatures, three cases of HEV-associated myocarditis have been reported. ${ }^{85}$ Furthermore, HEV infection has been correlated with thyroid diseases. These include autoimmune thyroiditis, subacute thyroiditis and Grave's thyrotoxicosis. ${ }^{86-88}$ In addition, a case of Henoch-Schönlein purpura triggered by acute HEV infection ${ }^{89}$ and another case of HEV-induced myasthenia Gravis have been described. ${ }^{90}$ Lastly, HEV infection may cause acute polyarthritis. ${ }^{91,92}$

\section{CONCLUSION}

Several extrahepatic manifestations and diseases have been documented during acute and chronic HEV infection. Neurologic diseases are demonstrated to be the most common extrahepatic manifestations of HEV infection, followed by hematological disorders and kidney injury. However, the pathophysiology of these manifestations and the causal relation with HEV infection remain ambiguous. Therefore, further studies are needed to estimate the epidemiological characteristics of HEV-related extrahepatic manifestations and to elucidate their underlying pathogenetic mechanisms.

\section{Author's contribution}

FSF: Data selection, writing, study design, IVM: writing, DKC: Supervision, study design, writing

\section{Conflicts of Interest}

The authors have no conflicts to disclose.

\section{REFERENCES}

1. Balayan MS, Andjaparidze AG, Savinskaya SS, Ketiladze ES, Braginsky DM, Savinov AP, et al. Evidence for a virus in non- $A$, non-B hepatitis transmitted via the fecal-oral route. Intervirology 1983;20:23-31.

2. Reyes GR, Purdy MA, Kim JP, Luk KC, Young LM, Fry KE, et al. Isolation of a cDNA from the virus responsible for enterically transmitted non-A, non-B hepatitis. Science 1990;247:1335-1339.

3. Rein DB, Stevens GA, Theaker J, Wittenborn JS, Wiersma ST. The global burden of hepatitis E virus genotypes 1 and 2 in 2005. Hepatology 2012;55:988-997.

4. Dalton HR, Hunter JG, Bendall RP. Hepatitis E. Curr Opin Infect Dis 2013;26:471-478.

5. O'Hara Z, Crossan C, Craft J, Scobie L. First report of the presence of hepatitis $\mathrm{E}$ virus in Scottish-harvested shellfish purchased at retail level. Food Environ Virol 2018;10:217-221.

6. La Rosa G, Proroga YTR, De Medici D, Capuano F, laconelli M, Della Libera $S$, et al. First detection of hepatitis $E$ Virus in shellfish and in seawater from production areas in Southern Italy. Food Environ Virol 2018;10:127-131.

7. Sridhar S, Teng JLL, Chiu TH, Lau SKP, Woo PCY. Hepatitis E virus genotypes and evolution: emergence of camel hepatitis $E$ variants. Int J Mol Sci 2017;18:869.

8. Aggarwal R. Diagnosis of hepatitis E. Nat Rev Gastroenterol Hepatol 2013;10:24-33

9. European Association for the Study of the Liver. EASL Clinical Practice Guidelines on hepatitis E virus infection. J Hepatol 2018:68:1256-1271.

10. Kar P, Sengupta A. A guide to the management of hepatitis $E$ infection during pregnancy. Expert Rev Gastroenterol Hepatol 2019;13:205-211.

11. Kamar N, Selves J, Mansuy JM, Ouezzani L, Péron JM, Guitard J, et al. Hepatitis E virus and chronic hepatitis in organ-transplant recipients. N Engl J Med 2008;358:811-817.

12. Kamar N, Marion O, Abravanel F, Izopet J, Dalton HR. Extrahepatic manifestations of hepatitis E virus. Liver Int 2016;36:467-472.

13. Pischke S, Hartl J, Pas SD, Lohse AW, Jacobs BC, Van der Eijk AA. Hepatitis E virus: infection beyond the liver? J Hepatol 2017;66:10821095.

14. Bose PD, Das BC, Hazam RK, Kumar A, Medhi S, Kar P. Evidence of extrahepatic replication of hepatitis $E$ virus in human placenta. $J$ Gen Virol 2014;95(Pt 6):1266-1271.

15. Rivero-Juarez A, Frias M, Rodriguez-Cano D, Cuenca-López F, Rivero A. Isolation of hepatitis $E$ virus from breast milk during acute infection. Clin Infect Dis 2016;62:1464.

16. Geng Y, Zhao C, Huang W, Harrison TJ, Zhang H, Geng K, et al. Detection and assessment of infectivity of hepatitis $E$ virus in urine. J Hepatol 2016;64:37-43.

17. McLean BN, Gulliver J, Dalton HR. Hepatitis E virus and neurological disorders. Pract Neurol 2017;17:282-288.

18. Dalton HR, van Eijk JJJ, Cintas P, Madden RG, Jones C, Webb GW, et al. Hepatitis E virus infection and acute non-traumatic neurological 
Fotios S. Fousekis, et al. Extrahepatic manifestations of hepatitis $\mathrm{E}$

injury: a prospective multicentre study. J Hepatol 2017;67:925-932.

19. Abravanel F, Pique J, Couturier E, Nicot F, Dimeglio C, Lhomme S, et al. Acute hepatitis $E$ in French patients and neurological manifestations. J Infect 2018;77:220-226.

20. Wang Y, Wang S, Wu J, Jiang Y, Zhang H, Li S, et al. Hepatitis E virus infection in acute non-traumatic neuropathy: a large prospective case-control study in China. EBioMedicine 2018;36:122-130.

21. Horvatits T, Pischke S. Extrahepatic manifestations and HEV, the genotype matters. EBioMedicine 2018;36:3-4.

22. Meena AK, Khadilkar SV, Murthy JM. Treatment guidelines for Guillain-Barré syndrome. Ann Indian Acad Neurol 2011;14(Suppl 1):S73S81.

23. van den Berg B, van der Eijk AA, Pas SD, Hunter JG, Madden RG, Tio-Gillen AP, et al. Guillain-Barré syndrome associated with preceding hepatitis E virus infection. Neurology 2014;82:491-497.

24. Stevens O, Claeys KG, Poesen K, Saegeman V, Van Damme P. Diagnostic challenges and clinical characteristics of hepatitis $E$ virusassociated Guillain-Barré syndrome. JAMA Neurol 2017;74:26-33.

25. Geurtsvankessel CH, Islam Z, Mohammad QD, Jacobs BC, Endtz HP, Osterhaus AD. Hepatitis $E$ and Guillain-Barre syndrome. Clin Infect Dis 2013;57:1369-1370.

26. Seror P. Neuralgic amyotrophy. An update. Joint Bone Spine 2017;84:153-158.

27. van Eijk JJ, Madden RG, van der Eijk AA, Hunter JG, Reimerink JH, Bendall RP, et al. Neuralgic amyotrophy and hepatitis E virus infection. Neurology 2014;82:498-503.

28. van Eijk JJJ, Dalton HR, Ripellino P, Madden RG, Jones C, Fritz M, et al. Clinical phenotype and outcome of hepatitis E virus-associated neuralgic amyotrophy. Neurology 2017;89:909-917.

29. Woolson KL, Forbes A, Vine L, Beynon L, McElhinney L, Panayi V, et al. Extra-hepatic manifestations of autochthonous hepatitis $E$ infection. Aliment Pharmacol Ther 2014;40:1282-1291.

30. Jha AK, Nijhawan S, Nepalia S, Suchismita A. Association of Bell's Palsy with hepatitis E virus infection: a rare entity. J Clin Exp Hepatol 2012:2:88-90

31. Bruffaerts R, Yuki N, Damme PV, Moortele MV, Wautier M, Lagrou $K$, et al. Acute ataxic neuropathy associated with hepatitis $E$ virus infection. Muscle Nerve 2015;52:464-465.

32. Sarkar P, Morgan C, ljaz S. Transverse myelitis caused by hepatitis E: previously undescribed in adults. BMJ Case Rep 2015;2015: bcr2014209031.

33. Pasha SA, Pasha SA, Suhasini T, Rao DA. Hepatitis E virus-associated acute encephalitic parkinsonism. J Assoc Physicians India 2018:66:92-93

34. Yadav KK, Rohatgi A, Sharma SK, Kulshrestha M, Sachdeva S, Pardasani V. Oculomotor palsy associated with hepatitis E infection. J Assoc Physicians India 2002;50:737.

35. Mengel AM, Stenzel W, Meisel A, Buning C. Hepatitis E-induced severe myositis. Muscle Nerve 2016;53:317-320.

36. Kejariwal D, Roy S, Sarkar N. Seizure associated with acute hepatitis E. Neurology 2001;57:1935.

37. Thapa R, Mallick D, Biswas B. Pseudotumor cerebri in childhood hepatitis E virus infection. Headache 2009;49:610-611.

38. Kamar N, Izopet J, Cintas P, Garrouste C, Uro-Coste E, Cointault 0 , et al. Hepatitis E virus-induced neurological symptoms in a kidney-transplant patient with chronic hepatitis. Am J Transplant 2010;10:1321-1324.

39. Despierres LA, Kaphan E, Attarian S, Cohen-Bacrie S, Pelletier J, Pouget J, et al. Neurologic disorders and hepatitis E, France, 2010. Emerg Infect Dis 2011;17:1510-1512.

40. Perrin HB, Cintas P, Abravanel F, Gérolami R, d'Alteroche L, Raynal $J N$, et al. Neurologic disorders in immunocompetent patients with autochthonous acute hepatitis E. Emerg Infect D 2015;21:19281934.

41. Dalton HR, Kamar N, van Eijk JJ, McLean BN, Cintas P, Bendall $\mathrm{RP}$, et al. Hepatitis E virus and neurological injury. Nat Rev Neurol 2016;12:77-85

42. Fritz $M$, Berger B, Schemmerer M, Endres D, Wenzel JJ, Stich O, et al. Pathological cerebrospinal fluid findings in patients with neuralgic amyotrophy and acute hepatitis E virus infection. J Infect Dis 2018;217:1897-1901.

43. Drave SA, Debing $Y$, Walter $S$, Todt $D$, Engelmann $M$, Friesland $M$, et al. Extra-hepatic replication and infection of hepatitis $E$ virus in neuronal-derived cells. J Viral Hepat 2016;23:512-521.

44. Bazerbachi F, Haffar S, Garg SK, Lake JR. Extra-hepatic manifestations associated with hepatitis $\mathrm{E}$ virus infection: a comprehensive review of the literature. Gastroenterol Rep (Oxf) 2016;4:1-15.

45. Kamar N, Weclawiak H, Guilbeau-Frugier C, Legrand-Abravanel F, Cointault $\mathrm{O}$, Ribes $\mathrm{D}$, et al. Hepatitis $\mathrm{E}$ virus and the kidney in solidorgan transplant patients. Transplantation 2012;93:617-623.

46. Del Bello A, Guilbeau-Frugier C, Josse AG, Rostaing L, Izopet J, Kamar N. Successful treatment of hepatitis E virus-associated cryoglobulinemic membranoproliferative glomerulonephritis with ribavirin. Transpl Infect Dis 2015;17:279-283.

47. Taton B, Moreau K, Lepreux S, Bachelet T, Trimoulet P, De Ledinghen $V$, et al. Hepatitis E virus infection as a new probable cause of de novo membranous nephropathy after kidney transplantation. Transpl Infect Dis 2013;15:E211-E215.

48. Agrawal P, Kumar V, Kumar A, Sachdeva MUS, Malhotra P, Nada R. Monoclonal gammopathy of renal significance triggered by viral $E$ hepatitis. Indian J Nephrol 2019;29:50-52.

49. Marion O, Abravanel F, Del Bello A, Esposito L, Lhomme S, PuissantLubrano B, et al. Hepatitis E virus-associated cryoglobulinemia in solid-organ-transplant recipients. Liver Int 2018;38:2178-2189.

50. Pischke S, Polywka S, Haag F, Iking-Konert C, Sterneck M, Lütgehetmann $\mathrm{M}$, et al. Association of hepatitis $\mathrm{E}$ virus and essential cryo- 
globulinemia? J Clin Virol 2015;67:23-24.

51. Chau TN, Lai ST, Lai JY, Yuen H. Haemolysis complicating acute viral hepatitis in patients with normal or deficient glucose-6-phosphate dehydrogenase activity. Scand J Infect Dis 1997;29:551-553.

52. Monga A, Makkar RP, Arora A, Mukhopadhyay S, Gupta AK. Case report: acute hepatitis $E$ infection with coexistent glucose-6-phosphate dehydrogenase deficiency. Can J Infect Dis 2003;14:230-231.

53. Au WY, Ngai CW, Chan WM, Leung RY, Chan SC. Hemolysis and methemoglobinemia due to hepatitis $\mathrm{E}$ virus infection in patient with G6PD deficiency. Ann Hematol 2011;90:1237-1238.

54. Jain AK, Sircar S, Jain M, Adkar S, Waghmare C, Chahwala F. Increased morbidity in acute viral hepatitis with glucose-6-phosphate dehydrogenase deficiency. Indian J Gastroenterol 2013;32:133-134.

55. Ahmad BS, Ahmad A, Jamil S, Abubakar Mohsin Ehsanullah SA, Munir A. Severe haemolysis and renal failure precipitated by hepatitis E virus in G6PD Deficient patient: a case report. J Pak Med Assoc 2018;68:1397-1399.

56. Abid S, Khan AH. Severe hemolysis and renal failure in glucose6-phosphate dehydrogenase deficient patients with hepatitis E. Am J Gastroenterol 2002;97:1544-1547.

57. Tibble JA, Ireland A, Duncan JR. Acute auto immune haemolytic anaemia secondary to hepatitis A infection. Clin Lab Haematol 1997;19:73-75.

58. Jin $S Q$, Chen XR, Wu XL, Han QX. A report of acute hepatitis $E$ with immunologic hemolysis. Zhonghua Gan Zang Bing Za Zhi 2005;13:120.

59. Leaf RK, O'Brien KL, Leaf DE, Drews RE. Autoimmune hemolytic anemia in a young man with acute hepatitis $E$ infection. Am J Hematol 2017;92:E77-E79.

60. Mishra P, Mahapatra M, Kumar R, Pati HP. Autoimmune hemolytic anemia and erythroid hypoplasia associated with hepatitis $\mathrm{E}$. Indian J Gastroenterol 2007;26:195-196.

61. Thapa R, Ghosh A. Childhood autoimmune hemolytic anemia following hepatitis E virus infection. J Paediatr Child Health 2009;45:7172.

62. Rauff B, Idrees M, Shah SA, Butt S, Butt AM, Ali L, et al. Hepatitis associated aplastic anemia: a review. Virol J 2011;8:87.

63. Zylberman M, Turdó K, Odzak A, Arcondo F, Altabert N, Munné S. Hepatitis $E$ virus-associated aplastic anemia. Report of a case. Medicina (B Aires) 2015;75:175-177.

64. Shah SA, Lal A, Idrees M, Hussain A, Jeet C, Malik FA, et al. Hepatitis $E$ virus-associated aplastic anaemia: the first case of its kind. J Clin Virol 2012;54:96-97.

65. Amarapurkar DN, Amarapurkar AD. Extrahepatic manifestations of viral hepatitis. Ann Hepatol 2002;1:192-195.

66. Stasi R, Chia LW, Kalkur P, Lowe R, Shannon MS. Pathobiology and treatment of hepatitis virus-related thrombocytopenia. Mediterr J Hematol Infect Dis 2009;1:e2009023.
67. Masood I, Rafiq A, Majid Z. Hepatitis E presenting with thrombocytopaenia. Trop Doct 2014;44:219-220.

68. Singh NK, Gangappa M. Acute immune thrombocytopenia associated with hepatitis E in an adult. Am J Hematol 2007;82:942-943.

69. Kaur S, Kulkarni KP, Mahajan A, Sibal A. Hemophagocytosis associated with hepatitis a and e coinfection in a young child. Indian J Hematol Blood Transfus 2011;27:117-118.

70. Leroy M, Coiffier G, Pronier C, Triquet L, Perdriger A, Guggenbuhl P. Macrophage activation syndrome with acute hepatitis $E$ during tocilizumab treatment for rheumatoid arthritis. Joint Bone Spine 2015;82:278-279.

71. Kamihira T, Yano K, Tamada Y, Matsumoto T, Miyazato M, Nagaoka $S$, et al. Case of domestically infected hepatitis $E$ with marked thrombocytopenia. Nihon Shokakibyo Gakkai Zasshi 2008;105:841846.

72. Mallet V, Bruneau J, Zuber J, Alanio C, Leclerc-Mercier S, RoqueAfonso AM, et al. Hepatitis E virus-induced primary cutaneous CD30(+) T cell lymphoproliferative disorder. J Hepatol 2017;67:13341339.

73. Forbes A, Woolson KL, Dalton HR. Letter: Monoclonal gammopathy of HEV infection. When is it significant? - authors' reply. Aliment Pharmacol Ther 2015;41:1028.

74. Riveiro-Barciela M, Bes M, Quer J, Valcarcel D, Piriz S, Gregori J, et al. Thrombotic thrombocytopenic purpura relapse induced by acute hepatitis E transmitted by cryosupernatant plasma and successfully controlled with ribavirin. Transfusion 2018;58:2501-2505.

75. Haffar S, Bazerbachi F, Prokop L, Watt KD, Murad MH, Chari ST. Frequency and prognosis of acute pancreatitis associated with fulminant or non-fulminant acute hepatitis A: a systematic review. Pancreatology 2017;17:166-175.

76. Parenti DM, Steinberg W, Kang P. Infectious causes of acute pancreatitis. Pancreas 1996;13:356-371.

77. Tsui $C Y$, Burch GE, Harb JM. Pancreatitis in mice infected with coxsackievirus B1. Arch Pathol 1972;93379-389.

78. Makharia GK, Garg PK, Tandon RK. Acute pancreatitis associated with acute hepatitis E infection. Trop Gastroenterol 2003;24:200201.

79. Jaroszewicz J, Flisiak R, Kalinowska A, Wierzbicka I, Prokopowicz D. Acute hepatitis $E$ complicated by acute pancreatitis: a case report and literature review. Pancreas 2005;30:382-384.

80. Raj M, Kumar K, Ghoshal UC, Saraswat VA, Aggarwal R, Mohindra $\mathrm{S}$. Acute hepatitis $\mathrm{E}$-associated acute pancreatitis: a single center experience and literature review. Pancreas 2015;44:1320-1322.

81. Haffar S, Bazerbachi F, Garg S, Lake JR, Freeman ML. Frequency and prognosis of acute pancreatitis associated with acute hepatitis $\mathrm{E}:$ a systematic review. Pancreatology 2015;15:321-326.

82. Deniel C, Coton T, Brardjanian S, Guisset M, Nicand E, Simon F. Acute pancreatitis: a rare complication of acute hepatitis E. J Clin 
Fotios S. Fousekis, et al. Extrahepatic manifestations of hepatitis $E$

Virol 2011;51:202-204.

83. Karanth SS, Khan Z, Rau NR, Rao K. Acute hepatitis E complicated by acute pancreatitis and multiorgan dysfunction. BMJ Case Rep 2014;2014:bcr2014203875.

84. Somani SK, Ghosh A, Awasthi G. Severe acute pancreatitis with pseudocyst bleeding due to hepatitis E virus infection. Clin J Gastroenterol 2009;2:39-42.

85. Premkumar M, Rangegowda D, Vashishtha C, Bhatia V, Khumuckham JS, Kumar B. Acute viral hepatitis E is associated with the development of myocarditis. Case Reports Hepatol 2015;2015:458056.

86. Dumoulin FL, Liese H. Acute hepatitis E virus infection and autoimmune thyroiditis: yet another trigger? BMJ Case Rep 2012;2012: bcr1220115441.

87. Martinez-Artola Y, Poncino D, García ML, Munné MS, González J, García DS. Acute hepatitis E virus infection and association with a subacute thyroiditis. Ann Hepatol 2015;14:141-142.

88. Hui AY, Chan HL, Chan FK, Leung NW, Sung JJ. Fulminant hepatic failure in a patient with inactive $\mathrm{HBsAg}$ carrier state, acute hepatitis E and thyrotoxicosis. Hepatol Res 2003;27:248-251.

89. Thapa R, Biswas B, Mallick D. Henoch-Schönlein purpura triggered by acute hepatitis E virus infection. J Emerg Med 2010;39:218-219.

90. Belbezier A, Deroux A, Sarrot-Reynauld F, Larrat S, Bouillet L. Myasthenia gravis associated with acute hepatitis $E$ infection in immunocompetent woman. Emerg Infect Dis 2014;20:908-910.

91. Bialé L, Lecoules S, Galéano-Cassaz C, Carmoi T, Algayres JP. Inflammatory polyarthralgia reveling acute hepatitis E. Presse Med 2013;42:365-367.

92. Serratrice J, Disdier P, Colson P, Ene N, de Roux CS, Weiller PJ. Acute polyarthritis revealing hepatitis E. Clin Rheumatol 2007;26:19731975. 